\title{
Analisis Tingkat Kepuasan Peserta Pelatihan AutoCAD Online untuk Pengabdian Masyarakat Terdampak Covid-19 dengan Metode Kirkpatrick Level I
}

\author{
Madi $^{1}$, Yoyok Setyo Hadiwidodo ${ }^{2}$, Tuswan ${ }^{2}$, Abdi Ismail ${ }^{2}$ \\ ${ }^{1}$ Institut Teknologi Sumatera, Indonesia \\ ${ }_{2}^{2}$ Institut Teknologi Sepuluh Nopember, Indonesia
}

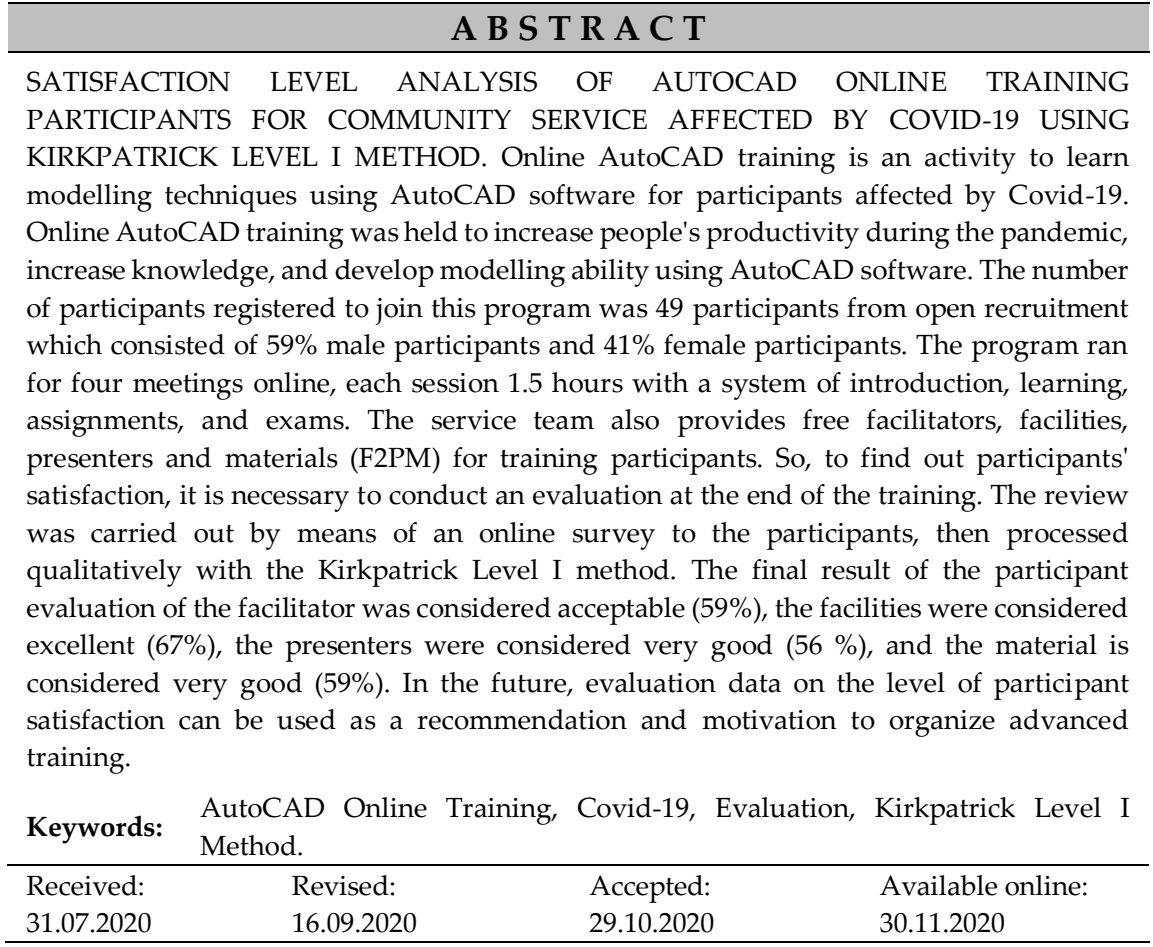

\section{Suggested citation:}

Madi, Hadiwidodo, Y. S., Tuswan, \& Ismail, A. (2020). Analisis tingkat kepuasan peserta pelatihan AutoCAD online untuk pengabdian masyarakat terdampak Covid-19 dengan metode Kirkpatrick Level I. Jurnal Pengabdian Pada Masyarakat, 5(4), 1065-1076. https://doi.org/10.30653/002.202054.689

Open Access I URL: http://ppm.ejournal.id/index.php/pengabdian/article/view/689

${ }^{1}$ Corresponding Author: Teknik Sistem Energi, Institut Teknologi Sumatera, Lampung Selatan 35365, Indonesia. Email: madi@tse.itera.ac.id 


\section{PENDAHULUAN}

Coronavirus Diseases-19 (Covid-19) merupakan salah satu jenis virus corona yang serumpun dengan Severe Acute Respiratory Syndrome (SARS) dan Middle East Respiratory Syndrome (MERS). Covid-19 pertama kali ditemukan di Kota Wuhan pada akhir tahun 2019 (Hui dkk, 2011). Penularan yang sangat cepat dari Covid-19 di berbagai belahan dunia, sehingga meresahkan kesehatan masyarakat, World Health Organization (WHO) telah menetapkannya sebagai bencana pandemi dunia (Dewi, 2020). Salah satu negara yang merasakan penyebaran yang sangat cepat adalah di Indonesia, mulai dari dua orang yang dinyatakan positif, hingga meninggal dunia, dan menyebarluas diberbagai wilayah Indonesia. Dengan itu, pemerintah Indonesia menetapkan sebagai bencana Nasional. Berbagai kebijakan dari pemerintah dilakukan untuk meminimalisir penyebaran Covid-19 di Indonesia, salah satunya adalah dengan ditutupnya kegiatan belajar mengajar (KBM) di dalam sekolah maupun di kampus dan digantikan dengan KBM online yang dilaksanakan di rumah masing-masing. Selama KBM online dapat menghambat berbagai sarana maupun pra-sarana. Sarana dan Prasarana adalah kunci mengatasi hambatan selama proses KBM online (Pangondian dkk, 2019). Motivasi dari para pengajar juga dibutuhkan untuk memberikan semangat belajar kepada para pelajar selama KBM online (Rusdiana dan Nugroho, 2020).

Seiring dengan berjalannya waktu, pembelajaran online telah biasa dilakukan oleh masyarakat dunia. Seperti kegiatan pelatihan online, seminar online (webinar), konferensi ilmiah online, praktikum online, dan kegiatan pendidikan lainnya yang bersifat online dengan menggunakan media meeting online. Hal tersebut juga dilakukan oleh Tim Pengabdi pada program ini dengan melakukan kegiatan pelatihan AutoCAD online untuk masyarakat terdampak Covid-19. Dalam pelatihan AutoCAD online itu, peserta pelatihan menilai kegiatannya bermanfaat (Hadiwidodo dkk, 2020). Namun, belum terdapat evaluasi khusus terkait kepuasan peserta pelatihan terhadap Fasilitator, Fasilitas, Pemateri, dan Materi (F2PM). Sehingga, dalam ini menganalisis kepuasan peserta terhadap F2PM dengan menggunakan metode Kirkpatrick Level I. Proses analisis dilakukan oleh penyelenggara pelatihan dengan menggunakan survei online. Penyelenggara pelatihan dianggap sebagai pusat rehabilitas atau penyegaran aspek pengetahuan dan keterampilan (Sutarto, 2013).

Evaluasi dalam pelatihan sangat diperlukan untuk mengetahui keberhasilan suatu program, sehingga hasil dapat diputuskan untuk dilanjutkan atau diberhentikan suatu program tersebut. Tujuan utama dari evaluasi suatu program untuk mengukur efektifitas dalam keberhasilan penyelenggaraan pelatihan (Widyastuti \& Purwana ES, 2015). Pada dasarnya program pelatihan pengabdian kepada masyarakat bertujuan untuk memberikan kebermanfaatan, meningkatkan kompetisi, pengetahuan, dan wawasan agar meningkatkan maupun menambah kemampuan.

Teori tentang evaluasi suatu pelatihan pertama kali ditemukan oleh Kirkpatrick pada tahun 1998. Teori itu kemudian dikenal dengan, "The Four Levels Techniques for Evaluating Training Programs." Keempat level itu adalah, Level I (reaction) merupakan evaluasi tingkat kepuasan peserta terhadap pelaksanaan pelatihan, Level II (learning) merupakan evaluasi tingkat kemampuan dari peserta dalam penguasaan materi pelatihan, Level III (behavior) merupakan evaluasi tingkat kemampuan dari peserta dalam mengimplementasikan hasil pelatihan di lingkungannya, Level IV (result) 
merupakan evaluasi tingkat pengaruh peserta pada dampak hasil pelatihan terhadap kinerja di lingkungannya.

Metode Analisis Kirkpatrick Level I sangat penting dilakukan untuk mengetahui tingkat kepuasan peserta pada pelatihan yang telah dilaksanakan. Pentingnya tahap reaksi peserta pelatihan merupakan salah satu penentu dari keberhasilan sebuah program pelatihan karena tim pengabdi dapat mengetahui apa yang dirasakan peserta setelah mengikuti pelatihan, serta terdapat saran dan masukan dari para peserta pelatihan (Kirkpatrick, 2007).

Dalam melaksanakan evaluasi Level I ada beberapa tahapan yang perlu dilakukan yaitu, membuat daftar item yang menyangkut semua pelaksanaan program seperti kepuasaan peserta terhadap F2PM. Reaksi yang didapat di desain secara kuantifikasi dan diberikan ruang untuk memberikan komentar alasan dari peserta. Setelah itu, diperlukan saran dan perbaikan dari peserta, dan dijaga rahasia data identitas peserta. Terakhir, lakukanlah proses evaluasi secarai baik dan benar untuk memperoleh hasil yang maksimal (Ritonga dkk, 2019).

Pada publikasi sebelumnya dalam program pelatihan AutoCAD online telah berhasil melaksanakan kegiatan dan respon dari peserta menunjukkan kesannya dominan memilih memuaskan, dengan presentase kepuasan dari pertemuan pertama sampai keempai berturut-turut adalah 80\%, 75\%,65\%, 55\%. Adapun pendapat dari peserta terhadap pelatihan AutoCAD online dominan menilai baik, dengan presentase dari pertemuan pertama sampai keempai adalah $57 \%$, 65\%, 61\%, dan $67 \%$. Sedangkan pada hasil penilaian kepuasan peserta terhadap pengaruh pelatihan AutoCAD online terhadap kebermanfaatan peserta dominan memilih bermanfaat, dengan presentase pertemuan pertama sampai keempat adalah $72 \%, 71 \%, 59 \%$, dan $61 \%$ (Hadiwidodo dkk, 2020). Berdasarkan hal itu, program pengabdian itu dinilai telah memuaskan peserta. Namun, evaluasi peserta tersebut masih secara umum, evaluasi belum dilakukan analisis secara khusus. Sehingga dalam studi ini menganalisis tingkat kepuasan peserta pelatihan AutoCAD online secara lebih khusus dengan item yang dinilai F2PM, dengan menggunakan metode Kirkpatrick Level I.

Tujuan dari adanya studi analisis kepuasan peserta ini agar tim pengabdi mengetahui reaksi dari peserta setelah mengikuti pelatihan AutoCAD online. Sehingga, tim pengabdi dapat memutuskan untuk dapat melanjutkan atau tidaknya program ini kedepannya. Harapan dari program ini juga supaya masyarakat yang terdampak Covid-19 tetap produktif selama pandemi berlangsung, dan mengasah kemampuan mendesain gambar teknik seperti rumah, sehingga bisa menjadi bekal membuka bisnis jasa desainer yang secara tidak langsung dapat meningkatkan taraf ekonomi masyarakat selama pandemi Covid-19.

\section{METODE}

\section{Metode Pelaksanaan Program Pengabdian}

Tahapan pelaksanaan program ini adalah, dimulai dari pre-training, training, dan pasca- pasca-training digambarkan pada Gambar 1. 


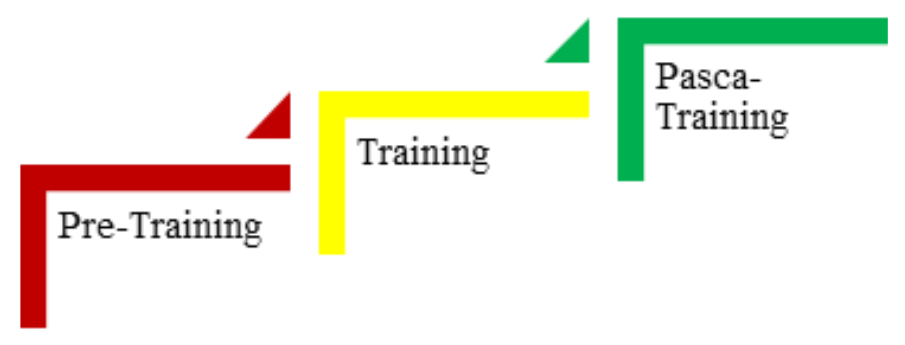

Gambar 1. Metode pelaksanaan program

Gambar 1 telah menunjukkan bahwa program ini dilaksanakan seperti sebuah tangga, jika program sudah selesai maka melakukan program lainnya yang lebih tinggi posisinya. Dalam hal ini, tangga pertama adalah tahap pre-training yaitu, tahap persiapan tim pengabdi sebelum terlaksananya suatu program. Adapun yang telah dipersiapkan seperti pelaksanaan open recruitment peserta yang mengikuti pelatihan. Selain itu, pembuatan media massa seperti website resmi tim pengabdi yang dapat diakses www.autocadcovid.com dan instagram di www.instagram.com/autocadcovid. Tim pengabdi juga membuat modul sebagai bahan pembelajaran dan aplikasi meeting online.

Tahap kedua adalah training yaitu suatu tahap inti dari program ini. Selama pelatihan tim pengabdi telah mempersiapkan media pembelajaran untuk para peserta, bukan hanya di media meeting online, namun di media massa seperti instagram, website dan grup whatsapp untuk menjaga informasi yang lebih baik. Tahap training berlangsung selama empat kali pertemuan selama 1,5 jam tiap pertemuannya. Pertemuan pertama membahas materi pengantar dan pengenalan menggambar teknik, kedua menggambar teknik dengan AutoCAD dan penugasan, ketiga penataan gambar, skala, dan print serta penugasan, keempat ujian akhir dengan mendesain rumah. Adapun dokumentasi selama pelatihan AutoCAD online dapat ditunjukkan pada Gambar 2. Pelatihan dilaksanakan dengan menggunakan aplikasi Google Meet karena dapat diakses secara gratis tanpa batas jumlah peserta selama pandemi berlangsung.

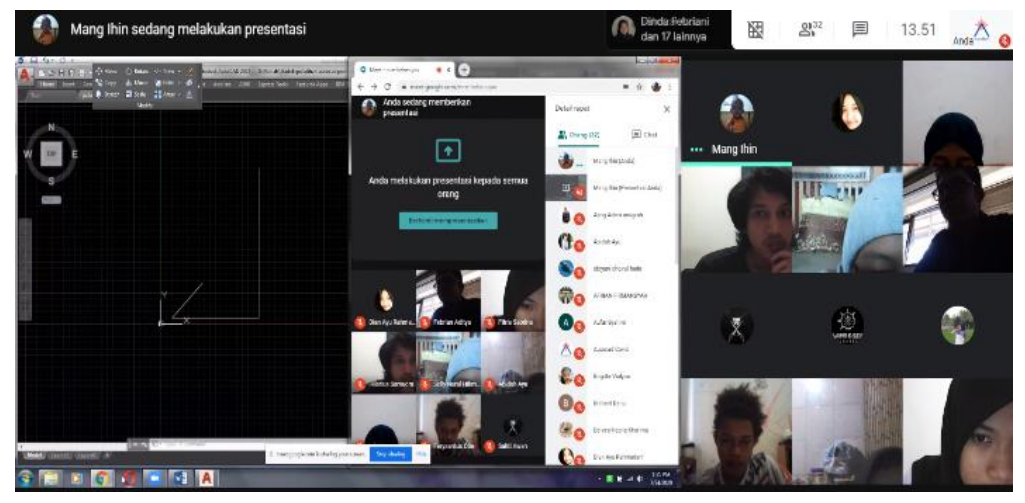

Gambar 2. Dokumentasi selama training

Tahap ketiga adalah tahap pasca-training yaitu, tahap setelah terlaksananya program pelatihan. Dalam hal ini dilakukan survei kepuasan online yang diisi langsung oleh para peserta pelatihan. Survei kepuasan juga sebagai syarat peserta untuk mendapatkan sertifikat. Sehingga, pada tahap ini tim pengabdi mendapatkan data 
reaksi peserta terhadap program pelatihan ini, yang kemudian diolah secara deskritif kuantitatif menggunakan metode analisis Kirkpatrick Level I.

\section{Metode Analisis Tingkat Kepuasan Peserta}

Dalam mengetahui reaksi tingkat kepuasan peserta pelatihan AutoCAD online, tim pengabdi menggunakan metode Kirkpatrick Level I. Adapun item yang menjadi bahan survei adalah Fasilitator, Fasilitas, Pemateri, dan Materi (F2PM). Fasilitator adalah tim pengabdi dalam program ini yang telah mengurus mulai dari pre-training, training, dan pasca-training. Fasilitator bisa disebut juga sebagai panitia program yang telah menyediakan fasilitas untuk para peserta sela program. Fasilitas merupakan bahan yang digunakan dan dibutuhkan para peserta. Adapun fasilitas yang disediakan dalam program ini adalah, modul pembelajaran, ppt bahan materia, media website, media instagram, grup Whatsapp, google meet yang semuanya dapat diakses secara gratis. Pemateri merupakan orang yang memberikan materi untuk para peserta karena pengalaman dan wawasan ilmunya yang telah memadai untuk mengajarkan para peserta pelatihan. Materi adalah yang menjadi bahan referensi belajar untuk para peserta.

Tabel 1. Skala angka evaluasi

\begin{tabular}{ll}
\hline Skala Angka & Keterangan \\
\hline 1 & Sangat Buruk \\
2 & Buruk \\
3 & Baik \\
4 & Sangat Baik \\
\hline
\end{tabular}

Keempat item yang menjadi bahan penilaian peserta melalui survei online itu, dilakukan dengan cara evaluasi skala angka sesuai dengan Cronbach's Alpha Level (Ahdika, 2017). Angka yang digunakan adalah 1 sampai 4, dengan kualitas sangat buruk, buruk, baik, dan sangat baik. Sedangkan kualitas penilaian "cukup" tidak ada karena sebagian besar peserta pelatihan akan memilih cukup sebagai kualitas yang paling aman dibandingkan yang lainnya. Adapun skala angka yang digunakan dalam program ini dapat ditunjukkan pada Tabel 1.

Survei online yang diberikan oleh tim pengabdi untuk para peserta pelatihan berisi berbagai pertanyaan yang perlu dijawab oleh peserta dengan merahasiakan identitas pserta. Adapun daftar pertanyaan yang terdapat dalam survei online dapat ditunjukkan pada Tabel 2.

Tabel 2. Item survei analisis kepuasan peserta

\begin{tabular}{lll}
\hline No & Item survei kepuasan & Keterangan nilai \\
\hline Penilaian terhadap Fasilitator & \\
1 & $\begin{array}{l}\text { Skala angka penilaian untuk } \\
\text { fasilitator }\end{array}$ & Penilaian skala angka 1-4 \\
2 & Alasan memberikan penilaian & $\begin{array}{l}\text { Penilaian deskripsi alasan memberi } \\
\text { nilai 1-4 }\end{array}$ \\
& untuk fasilitator & Penilaian deskripsi saran untuk \\
3 & Saran untuk fasilitator & fasilitator \\
\hline
\end{tabular}




\begin{tabular}{|c|c|c|}
\hline No & Item survei kepuasan & \multirow{2}{*}{ Keterangan nilai } \\
\hline \multicolumn{2}{|c|}{ Penilaian terhadap Fasilitator } & \\
\hline \multicolumn{3}{|c|}{ Penilaian terhadap Fasilitas } \\
\hline 1 & $\begin{array}{l}\text { Skala angka penilaian untuk } \\
\text { fasilitas }\end{array}$ & Penilaian skala angka 1-4 \\
\hline 2 & $\begin{array}{l}\text { Alasan memberikan penilaian } \\
\text { untuk fasilitas }\end{array}$ & $\begin{array}{l}\text { Penilaian deskripsi alasan memberi } \\
\text { nilai 1-4 }\end{array}$ \\
\hline 3 & Saran untuk fasilitas & Penilaian deskripsi saran untuk fasilitas \\
\hline \multicolumn{3}{|c|}{ Penilaian terhadap Pemateri } \\
\hline 1 & $\begin{array}{l}\text { Skala angka penilaian untuk } \\
\text { pemateri }\end{array}$ & Penilaian skala angka 1-4 \\
\hline 2 & $\begin{array}{l}\text { Alasan memberikan penilaian } \\
\text { untuk pemateri }\end{array}$ & $\begin{array}{l}\text { Penilaian deskripsi alasan memberi } \\
\text { nilai } 1-4\end{array}$ \\
\hline 3 & Saran untuk pemateri & $\begin{array}{l}\text { Penilaian deskripsi saran untuk } \\
\text { pemateri }\end{array}$ \\
\hline \multicolumn{3}{|c|}{ Penilaian terhadap Materi } \\
\hline 1 & Skala angka penilaian untuk materi & Penilaian skala angka 1-4 \\
\hline 2 & $\begin{array}{l}\text { Alasan memberikan penilaian } \\
\text { untuk materi }\end{array}$ & $\begin{array}{l}\text { Penilaian deskripsi alasan memberi } \\
\text { nilai 1-4 }\end{array}$ \\
\hline 3 & Saran untuk materi & Penilaian deskripsi saran untuk materi \\
\hline \multicolumn{3}{|c|}{ Penilaian Kebermanfaatan dan Keberlanjutan } \\
\hline 1 & Motivasi dan tujuan awal & $\begin{array}{l}\text { Deskripsi motivasi dan tujuan awal } \\
\text { peserta }\end{array}$ \\
\hline 2 & Tingkat kebermanfaatan & $\begin{array}{l}\text { Penilaian skala angka 1-4 dan pilihan } \\
\text { Ya atau Tidak }\end{array}$ \\
\hline 3 & Manfaat yang diperoleh & Penilaian deskripsi \\
\hline 4 & Kesesuaian dengan tujuan & Penilaian pilihan Ya atau Tidak \\
\hline 5 & Pilihan Keberlanjutan & Penilaian pilihan Ya atau Tidak \\
\hline 6 & Alasan Keberlanjutan & $\begin{array}{l}\text { Penilaian deskripsi alasan memilih Ya } \\
\text { atau Tidak }\end{array}$ \\
\hline
\end{tabular}

\section{HASIL DAN PEMBAHASAN}

\section{Hasil Kepuasan Terhadap Fasilitator}

Hasil reaksi kepuasan peserta terhadap program ini pada item fasilitator dapat ditunjukkan dalam diagram batang pada Gambar 3. Skala penilaian yang digunakan adalah skala angka 1 (sangat buruk), 2 (buruk), 3 (baik), dan 4 (sangat baik). Presentase jumlah peserta adalah hasil dari pembagian jumlah peserta yang memilih skala angka penilaian fasilitator dengan jumlah peserta yang mengisi survei kepuasan, kemudian dikalikan angka 100.

Gambar 3 menunjukkan bahwa peserta tidak ada yang memilih skala angka 1 (sangat buruk) dan 2 (buruk), dapat dilihat pada presentase jumlah pesertanya $0 \%$. Artinya, dalam hal ini secara tidak langsung peserta telah menunjukkan reaksi yang positif setelah mengikuti kegiatan pelatihan AutoCAD online. Hal tersebut dapat ditunjukkan pada diagram batang biru pada skala angka 3 (baik) dan 4 (sangat baik) yang menunjukkan presentase berturut-turut $59 \%$ dan $41 \%$. Bagimanapun, peserta lebih banyak memilih skala angka penilaian 3 (baik) dari pada skala angka lainnya. Hal 
itu dapat disimpulkan bahwa fasilitator sudah baik menjalankan program pengabdian masyarakat, yang mana fasilitator adalah tim pengabdi itu sendiri. Adapun alasan dari peserta yang lebih banyak memilih nilai baik terhadap item fasilitator berdasarkan hasil survei adalah, 1) berusaha keras; 2) humble; 3) fast response; 4) baik dalam mengontrol acara; 5) pengertian; dan 6) perhatian yang baik.

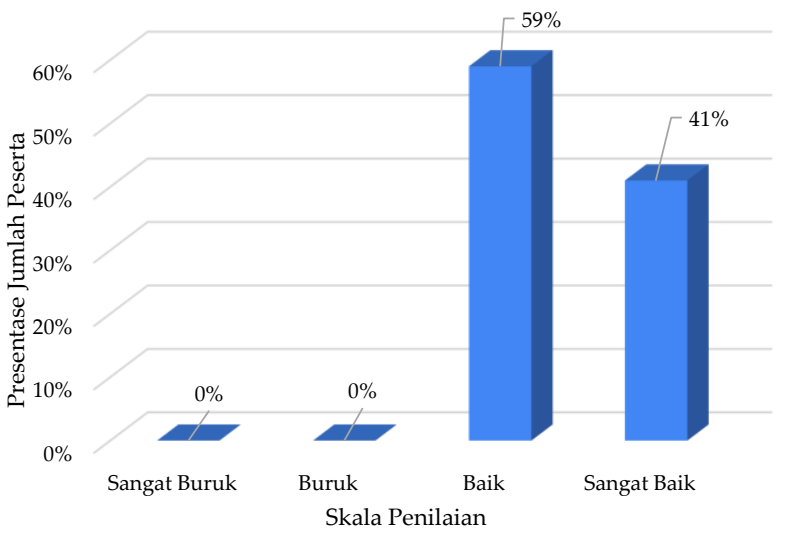

Gambar 3. Kepuasan peserta terhadap fasilitator

Adapun saran yang diberikan oleh peserta terhadap fasilitator berdasarkan hasil survei adalah, 1) manajemen waktu perlu diperbaiki; 2) jangan sering reschedule; 3) tugas jangan mendadak; dan 4) koordinasi yang baik ladi dengan pemateri. Saran dan masukan yang diberikan oleh peserta terhadap fasilitator sangat benar dan tim pengabdi menyadari masih belum bisa manajemen waktu dengan baik. Oleh karena itu, pelatihan selanjutnya tim pengabdi akan membuat schedule yang baik dan tepat.

\section{Hasil Kepuasan Terhadap Fasilitas}

Hasil reaksi kepuasan peserta terhadap program ini pada item fasilitas dapat ditunjukkan dalam diagram batang pada Gambar 4. Skala penilaian yang digunakan adalah skala angka 1 (sangat buruk), 2 (buruk), 3 (baik), dan 4 (sangat baik). Presentase jumlah peserta adalah hasil dari pembagian jumlah peserta yang memilih skala angka penilaian fasilitas dengan jumlah peserta yang mengisi survei kepuasan, kemudian dikalikan angka 100.

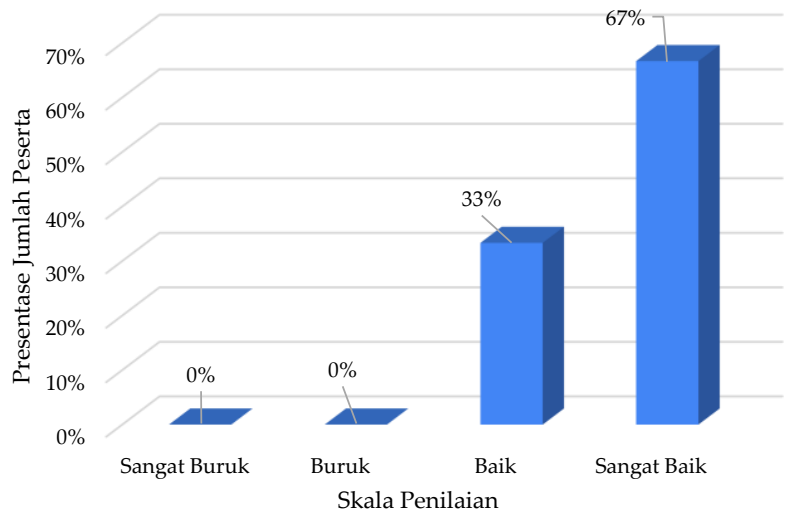

Gambar 4. Kepuasan peserta terhadap fasilitas 
Gambar 4 menunjukkan bahwa peserta tidak ada yang memilih skala angka 1 (sangat buruk) dan 2 (buruk), dapat dilihat pada presentase jumlah pesertanya $0 \%$. Artinya, dalam hal ini secara tidak langsung peserta telah menunjukkan reaksi yang positif setelah mengikuti kegiatan pelatihan AutoCAD online. Hal tersebut dapat ditunjukkan pada diagram batang biru pada skala angka 3 (baik) dan 4 (sangat baik) yang menunjukkan presentase berturut-turut $33 \%$ dan $67 \%$. Bagimanapun, peserta lebih banyak memilih skala angka penilaian 4 (sangat baik) dari pada skala angka lainnya. Hal itu dapat disimpulkan bahwa fasilitas yang diberikan oleh tim pengabdi sudah sangat baik, fasilitas yang dimaksud adalah modul, ppt, website dan instagram. Adapun alasan dari peserta yang lebih banyak memilih nilai sangat baik terhadap item fasilitas berdasarkan hasil survei kepuasan adalah, 1) modul dan ppt bahan pembelajaran sangat lengkap; 2) media informasi sangat jelas; 3) fasilitas gratis; 4) modul sangat informatif dan mudah dipahami; dan 5) semua fasilitas bagus dan lengkap.

Adapun saran yang diberikan oleh peserta terhadap fasilitas berdasarkan hasil survei adalah, 1) perlu adanya rekaman video pelatihan; 2) perlu adanya ruang Google Calass Form sebagai progres pembelajaran; 3) publikasi di media perlu dikembangkan; dan 4) fasilitas dibuat lebih menarik. Saran dan masukan yang diberikan oleh peserta terhadap fasilitas sangat benar dan tim pengabdi menyadari masih belum adanya video pelatihan yang menarik sebagai bahan pembelajaran peserta pelatihan. Oleh karena itu, pelatihan selanjutnya tim pengabdi akan membuat record dan video yang lebih menarik sebagai fasilitas media tambahan yang akan diupload di Youtube.

\section{Hasil Kepuasan Terhadap Pemateri}

Hasil reaksi kepuasan peserta terhadap program ini pada item pemateri dapat ditunjukkan dalam diagram batang pada Gambar 5. Skala penilaian yang digunakan adalah skala angka 1 (sangat buruk), 2 (buruk), 3 (baik), dan 4 (sangat baik). Presentase jumlah peserta adalah hasil dari pembagian jumlah peserta yang memilih skala angka penilaian pemateri dengan jumlah peserta yang mengisi survei kepuasan, kemudian dikalikan angka 100.

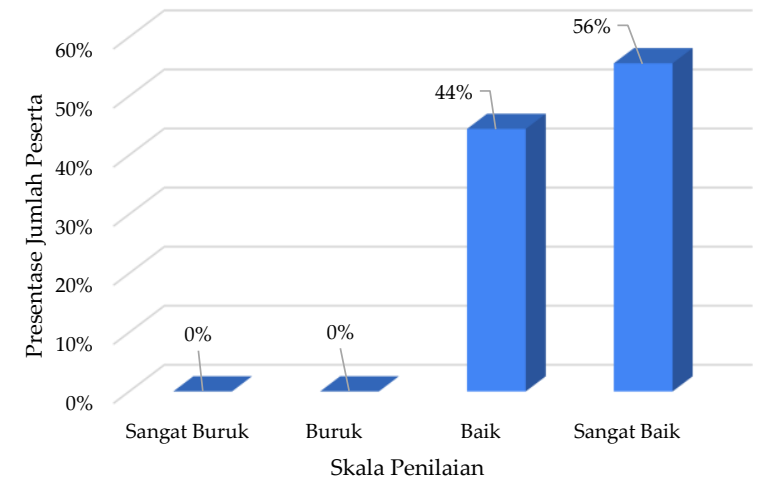

Gambar 5. Kepuasan peserta terhadap pemateri

Gambar 5 menunjukkan bahwa peserta tidak ada yang memilih skala angka 1 (sangat buruk) dan 2 (buruk), dapat dilihat pada presentase jumlah pesertanya $0 \%$. Artinya, dalam hal ini secara tidak langsung peserta telah menunjukkan reaksi yang 
positif setelah mengikuti kegiatan pelatihan AutoCAD online. Hal tersebut dapat ditunjukkan pada diagram batang biru pada skala angka 3 (baik) dan 4 (sangat baik) yang menunjukkan presentase berturut-turut $44 \%$ dan $56 \%$. Bagimanapun, peserta lebih banyak memilih skala angka penilaian 4 (sangat baik) dari pada skala angka lainnya. Hal itu dapat disimpulkan bahwa pemateri sudah sangat baik menjalankan program pengabdian masyarakat, yang mana pemateri merupakan orang yang memberikan materi pembelajaran selama empat kali pertemuan. Adapun alasan dari peserta yang lebih banyak memilih nilai sangat baik terhadap item pemateri berdasarkan dari hasil survei adalah, 1) mudah dipahami; 2) keren; 3) totalitas tinggi; 4) sangat jelas; 5) responsif; 6) sangat bagus; dan 7) sangat baik.

Adapun saran yang diberikan oleh peserta terhadap pemateri berdasarkan hasil survei adalah, 1) lebih sabar dan santai; 2) waktu perlu ditargetkan; 3) koordinasi dengan panitia; dan 4) jangan terlalu cepat. Saran dan masukan yang diberikan oleh peserta terhadap pemateri sangat benar dan tim pengabdi sangat menyadari bahwa pemateri masih terlalu cepat dalam penyampaian. Oleh karena itu, pelatihan selanjutnya pemateri akan lebih santai, dan tidak cepat dalam penyampaian pemateri.

\section{Hasil Kepuasan Terhadap Materi}

Hasil reaksi kepuasan peserta terhadap program ini pada item pemateri dapat ditunjukkan dalam diagram batang pada Gambar 6. Skala penilaian yang digunakan adalah skala angka 1 (sangat buruk), 2 (buruk), 3 (baik), dan 4 (sangat baik). Presentase jumlah peserta adalah hasil dari pembagian jumlah peserta yang memilih skala angka penilaian materi dengan jumlah peserta yang mengisi survei kepuasan, kemudian dikalikan angka 100.

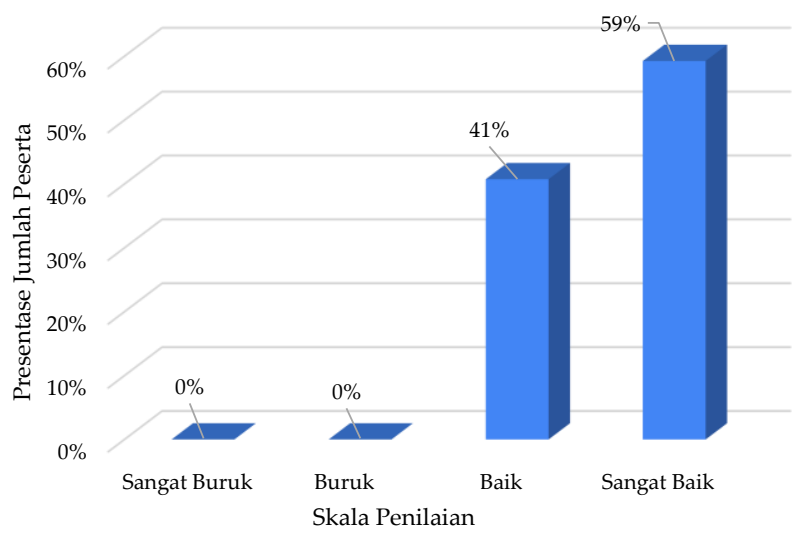

Gambar 6. Kepuasan peserta terhadap materi

Gambar 6 menunjukkan bahwa peserta tidak ada yang memilih skala angka 1 (sangat buruk) dan 2 (buruk), dapat dilihat pada presentase jumlah pesertanya $0 \%$. Artinya, dalam hal ini secara tidak langsung peserta telah menunjukkan reaksi yang positif setelah mengikuti kegiatan pelatihan AutoCAD online. Hal tersebut dapat ditunjukkan pada diagram batang biru pada skala angka 3 (baik) dan 4 (sangat baik) yang menunjukkan presentase berturut-turut $59 \%$ dan $41 \%$. Bagimanapun, peserta lebih banyak memilih skala angka penilaian 4 (sangat baik) dari pada skala angka lainnya. 
Hal itu dapat disimpulkan bahwa materi yang diberikan sudah sangat baik, yang mana materi merupakan bahan yang disampaikan oleh pemateri. Adapun alasan dari peserta yang lebih banyak memilih angka nilai sangat baik terhadap item materi berdasarkan hasil survei adalah, 1) mudah dipahami; 2) sangat baik; 3) sangat bermanfaat; 4) sangat bagus; 5) sangat menarik; dan 6) lengkap.

Adapun saran yang diberikan oleh peserta terhadap materi berdasarkan hasil survei adalah, 1) diperdalam; 2) dikembangkan lagi; 3) diperlengkap; dan 4) diperdetail.. Saran dan masukan yang diberikan oleh peserta terhadap materi sangat benar dan tim pengabdi menyadari bahwa materi kedepannya harus diperlengkap lagi Oleh karena itu, pelatihan selanjutnya tim pengabdi akan membuat materi yang lebih detail, lengkap, dan menarik lagi.

\section{Hasil Kebermanfaatan dan Keberlanjutan}

Hasil penilaian tingkat kebermanfaatan dalam program ini berdasarkan survei penilaian Ya atau Tidak, $100 \%$ peserta memilah Ya. Artinya, pelatihan AutoCAD online telah memberikan nilai kebermanfaatan kepada peserta. Adapun reaksi peserta terhadap tingkat kebermanfaatan program dapat ditunjukkan pada Gambar 7. Skala angka penilaian yang digunakan 1 (tidak bermanfaat), 2 (kurang bermanfaat), 3 (bermanfaat), dan 4 (sangat bermanfaat).

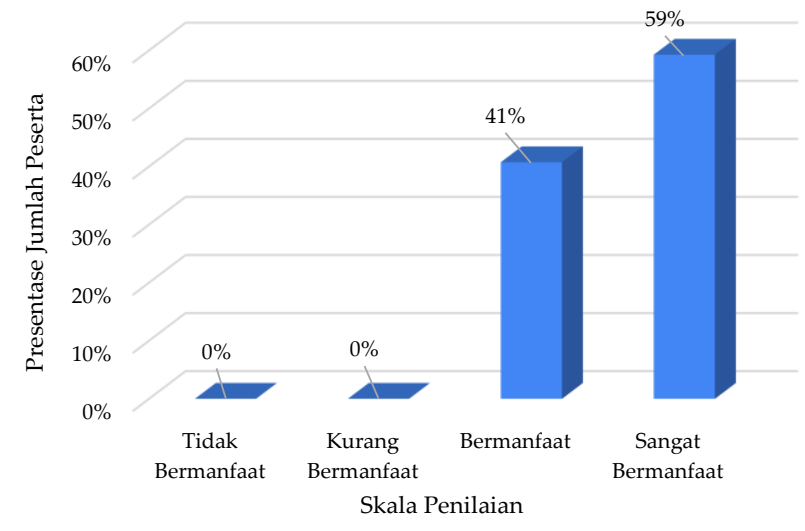

Gambar 7. Reaksi peserta terhadap tingkat kebermanfaatan program

Gambar 7 telah menunjukkan bahwa peserta lebih banyak memilih skala angka nilai 4 (sangat bermanfaat). Artinya, hal ini sangat sesuai dengan penilaian peserta sebelumnya yang memilih Ya (bermanfaat). Dalam hal ini presentase jumlah peserta yang memilih bermanfaat dan sangat bermanfaat berturut-turut $41 \%$ dan $59 \%$.

Adapun kebermanfaatan yang diperoleh para peserta berdasarkan survei adalah, a) mendapatkan soft skill; b) mengerti tool basic AutoCAD; c) memahami dasar-dasar AutoCAD; d) memperoleh ilmu baru; e) mengetahui fungsi dan perintah pada AutoCAD; f) menambah teman; g) termotivasi mendalami AutoCAD; h) bisa mendesain gambar teknik; i) mampu menggunakan AutoCAD; dan j) mampu membuat desain denah rumah.

Hasil penilaian tingkat keberlanjutan dalam program ini berdasarkan survei penilaian Ya atau Tidak, 100\% peserta memilah Ya. Artinya, 100\% peserta pelatihan berharap pelatihan ini dapat diadakan keberlanjutan. Hal itu didukung dengan 
terlaksananya kegiatan ini $100 \%$ peserta memilih telah sesuai dengan motivasi dan tujuan awal. Selain itu, $100 \%$ peserta juga memilihi program ini berlanjut dikarenakan berbagai harapan sepert, 1) dapat meningkatkan kemampuan menggambar teknik; 2) ingin lebih mahir lagi; 3) ingin memperoleh ilmu lebih dalam; 4) menunjang pendidikan di era industri 4.0;5) ingin mengerti AutoCAD lebih lanjut; 6) ingin mengerti 3D daesain dengan AutoCAD; 7) mengembangkan skill; 8) dan ingin menguasai semua fungsi dan tools AutoCAD.

\section{SIMPULAN}

Analisis tingkat kepuasan peserta pelatihan AutoCAD secara online telah selesai dengan menggunakan metode Kirkpatrick Level I. Hasil akhir evaluasi peserta terhadap Fasilitator dinilai baik (59\%), Fasilitas dinilai sangat baik (67\%), Pemateri dinilai sangat baik (56\%), dan Materi dinilai sangat baik (59\%). Harapan kedepannya, dengan adanya evaluasi tingkat kepuasan peserta dapat dijadikan rekomendasi dan motivasi untuk mengadakan pelatihan tingkat lanjut.

\section{Ucapan Terima Kasih}

Penulis mengucapkan terima kasih kepada segenap panitia dan tim pengabdi AUTOVID (AutoCAD Covid-19) yang telah menyelenggarakan pelatihan menggambar teknik secara online selama masa pandemi Covid-19 di Indonesia.

\section{REFERENSI}

Dewi, W. A. F. (2020). Dampak Covid-19 terhadap implementasi pembelajaran daring di sekolah dasar. Jurnal Ilmu Pendidikan, 2(1), 55-61.

Hadiwidodo, Y. S., Sholihin, S., Handayanu, H., Rochani, I., Syahroni, N., Pratikno, H., \& Madi, M. (2020). AUTOVID (AutoCAD Covid-19): Sebuah Media Pelatihan Software AutoCAD Secara Online untuk Masyarakat Terdampak Covid-19. SEWAGATI: Jurnal Pengabdian Masyarakat, 4(3), 1-7.

Hui, D. S., Azhar, E. I., Madani, T. A., Ntoumi, F., Kock, R., Dar, O., Ippolito, G., Mchugh, T.D., Memish, Z.A., Drosten, C., Zumla, A., Petersen, E. (2020). The continuing 2019nCoV epidemic threat of novel coronaviruses to global health - The latest 2019 novel coronavirus outbreak in Wuhan, China. International Journal of Infectious Diseases, 91, 264-266.

Kirkpatrick, D.L. (1998). Evaluating training program: The Four levels. San Fransisco: Berrett Koehlerr Publisher, Inc.

Kirkpatrick, D. L. (2007). Implementing the four levels: A Practical guide for effective evaluation of training of programs. San Fransisco: Berrett Koehlerr Publisher, Inc.

Pangondian, R. A., Santosa, P. I., \& Nugroho, E. (2019). Faktor-faktor yang mempengaruhi kesuksesan pembelajaran daring dalam revolusi industri 4.0. In Seminar Nasional Teknologi Komputer \& Sains (SAINTEKS), STMIK Budi Darma, Medan, 26 Januari 2019 (pp. 56-60). Medan: Green Press STMIK Budi Darma. 
Ritonga, R., Saepudin, A., \& Wahyudin, U. (2019). Penerapan model evaluasi kirkpatrick empat level dalam mengevaluasi program diklat di Balai Besar Pelatihan Pertanian (BPPP) Lembang. Jurnal Pendidikan Non-Formal. 14(1), 12-21.

Rusdiana, E., \& Nugroho, A. (2020). Respon mahasiswa pada pembelajaran daring bagi mahasiswa mata kuliah pengantar hukum Indonesia UNESA. Integralistik, 31(1), 112.

Sutarto, H. P. (2013). Strategi penggeseran paradigma pelatihan dari orientasi aktivitas di kelas ke hasil di tempat kerja. Jurnal Cakrawala Pendidikan, 32(2), 183-196.

Widyastuti, U., \& Purwana ES, D. (2015). Evaluasi pelatihan (training) level II berdasarkan teori the four levels Kirkpatrick. Jurnal Pendidikan Ekonomi dan Bisnis (JPEB), 3(2), 119-128.

\section{Copyright and License}

This is an open access article distributed under the terms of the Creative Commons Attribution 4.0 International License, which permits unrestricted use, distribution, and reproduction in any medium, provided the original work is properly cited. (C) 2020 Madi, Yoyok Setyo Hadiwidodo, Tuswan, Abdi Ismail. 